KONSELING: Jurnal Ilmiah Bimbingan dan Konseling

Vol.1, No.1, Oktober 2019, pp. 19-34

e-ISSN: 2686-2875

https://journal.ilininstitute.com/konseling

DOI: $10.31960 /$ konseling.v1i1.326

KONSEUNG

Received on 14/09/2019; Revised on 25/09/2019; Accepted on 13/10/2019; Published on:24/10/2019

\title{
Penerapan Dinamika Kelompok Dalam Guidance Courses Terhadap Kepercayaan Diri Siswa
}

\author{
Syarifuddin \\ Bimbingan dan Konseling, SMP Negeri 3 Libureng, Indonesia \\ ${ }^{*}$ Corespondensi Author Email: syarifuddin72@gmail.com
}

\begin{abstract}
Abstrak. Penelitian ini bertujuan untuk (1) mengetahui gambaran kepercayaan diri siswa dalam mengemukakan pendapat sebelum dan sesudah penerapan dinamika kelompok dalam guidance courses, (2) mengetahui pengaruh penerapan dinamika kelompok dalam guidance courses terhadap kepercayaan diri siswa dalam mengemukakan pendapat. Metode penelitian yang digunakan eksperimen dengan desain pre-eksperimental design menggunakan jenis the one group pre-test and post-test. Teknik pengumpulan data yang digunakan adalah skala psikologi dengan instrumen skala kepercayaan diri sebanyak 65 item. Populasinya siswa kelas VIII SMP Negeri 3 Libureng dengan sampel sebanyak 30 orang yang ditentukan secara purposive. Teknik analisis data yang digunakan adalah (1) analisis statistik deskriptif untuk menggambarkan kepercayaan diri siswa dalam mengemukakan pendapat sebelum dan sesudah perlakuan, (2) uji hipotesis dengan analisis t-test untuk mengetahui pengaruh penerapan dinamika kelompok dalam guidance courses sebelum dan sesudah perlakuan. Hasil penelitian menunjukkan bahwa dinamika kelompok dalam guidance courses terbukti berpengaruh secara signifikan terhadap kepercayaan diri siswa. Kepercayaan diri siswa meningkat setelah diberikan perlakuan diskusi kelompok dan role playing. Jadi teknik diskusi kelompok dan role playing dapat dijadikan alternatif untuk meningkatkan partisipasi siswa dalam kegiatan belajar kelompok dan bimbingan kelompok di kelas.
\end{abstract}

Kata Kunci: Dinamika Kelompok; guidance courses; role playing Kepercayaan diri.

\begin{abstract}
This study aims to (1) find out the picture of students' confidence in expressing opinions before and after the application of group dynamics in guidance courses, (2) determine the effect of applying group dynamics in guidance courses on student confidence in expressing opinions. The research method used was an experiment with a pre-experimental design using the one group type pre-test and post-test. The data collection technique used was a psychological scale with an confidence scale instrument of 65 items. The population is grade VIII students of SMP Negeri 3 Libureng with a sample of 30 people determined purposively. Data analysis techniques used are (1) descriptive statistical analysis to describe students' confidence in expressing opinions before and after treatment, (2) hypothesis testing with t-test analysis to determine the effect of applying group dynamics in guidance courses before and after treatment. The results showed that group dynamics in guidance courses proved to significantly influence student confidence. Students' confidence increases after being given the treatment of group discussion and role playing. So group discussion techniques and role playing can be used as alternatives to increase student participation in group learning activities and group guidance in class.
\end{abstract}

Keywords: Group Dynamics; guidance courses; role playing Confidence.

This is an open access article distributed under the Creative Commons Attribution License, which permits unrestricted use, distribution, and reproduction in any medium, provided the original work is properly cited. (C2019 by author.

\section{Pendahuluan}

Mengembangkan potensi dan kemampuan siswa baik secara perorangan maupun kelompok, telah dilaksanakan secara terencana di sekolah dan menjadi tekad bersama bagi guru, konselor, orang tua siswa dan masyarakat pada umumnya. Peran Guru Bimbingan dan Konseling dapat menghantarkan harapan sesuai potensi siswa (Suteja, 2017). Potensi dan kemampuan siswa dapat diaktualisasikan melalui layanan 
kegiatan pembelajaran dan bimbingan konseling dalam bentuk kelompok di sekolah. Layanan bimbingan konseling di sekolah adalah salah satu usaha pengembangan diri dalam lingkup pendidikan formal yang menekankan pada aspek psikologis dan kepribadian siswa sehingga terbentuk perilaku yang efektif, bermartabat dan lebih bertanggung jawab.

Untuk mengembangkan potensi diri siswa adalah melalui layanan bimbingan konseling yang terencana dan berkesinambungan dengan memanfaatkan kegiatan kelompok sebagai model pengembangannya. Dengan bimbingan konseling maka siswa akan memahami dirinya, mengarahkan dirinya, mengambil manfaat dari peluang-peluang yang dimiliki dalam rangka mengembangkan potensi yang dimilikinya (Salahuddin, 2010) Bentuk kegiatannya mencerminkan hubungan kerjasama yang harmonis sebagai prasyarat berlangsungnya komunikasi lebih efektif dan bermakna. Hubungan komunikasi yang dibangun dalam suasana kebersamaan dapat mendorong siswa memiliki rasa tanggung jawab, kepercayaan diri, kesadaraan siswa melakukan inisiatif, dan menempatkan diri secara wajar dalam kelompok. Kemampuan siswa membangun hubungan harmonis dalam kelompok tercermin pada perilaku siswa yang selalu mampu berkomunikasi dan berinteraksi secara baik sebagai sumber kekuatan dalam proses kelompok yang dapat mempengaruhi dinamika kelompok.

Dinamika kelompok merupakan kekuatan dan semangat yang beroperasi dalam kelompok dengan tujuan untuk mengembangkan kepribadian dan perilaku sosial siswa sebagai wujud interaksi satu sama lain. Kegiatan dinamika kelompok dapat memberikan kesempatan kepada setiap siswa untuk membangun relasi secara bersama-sama dalam mengatasi problem pribadi dan sosial melalui penukaran pikiran, diskusi dan merencanakan suatu aksi yang dilakukan bersama. Bekerja dalam kelompok perlu dirancang untuk meningkatkan cara dan mutu berinteraksi sedemikian rupa, sehingga menunjang pencapaian tujuan yang telah ditetapkan dan pengembangan kepribadian masing-masing siswa sebagai anggota yang tergabung dalam suatu kelompok (Winkel 2004:547). Mengembangkan diri siswa melalui kegiatan bimbingan kelompok mensyaratkan pemahaman dan keterampilan tertentu dari pemimpin kelompok. Konselor sekolah sebagai pemimpin dalam kegiatan kelompok harus memahami komponenkomponen yang berperanan dalam suatu proses kelompok sehingga terjadi kelompok yang efektif. Membentuk kelompok yang efektif dapat dilakukan oleh konselor sekolah dengan merancang dan mengelola serangkaian kegiatan yang memberikan pengalaman kepada siswa berinteraksi dalam kelompok. Melalui dinamika kelompok, siswa dapat belajar berinteraksi dan berkomunikasi antara satu dengan lainnya yang mendorong tumbuhnya kepercayaan diri siswa itu sendiri.

Proses membangun dan meningkatkan kepercayaan diri siswa merupakan permasalahan yang perlu mendapat penanganan oleh konselor sekolah. Konselor sebagai tenaga profesional memiliki tugas dan tanggung jawab membantu mengembangkan pengetahuan, keterampilan dan kepribadian siswa melalui kegiatan layanan bimbingan kelompok. Banyak siswa mengalami kesulitan mengemukakan pendapat dalam kegiatan kelompok karena kurang memahami potensi dirinya. Agar kelompok dapat efektif mengubah sikap siswa maka dibutuhkan pengetahuan yang cukup tentang dinamika dan prosesproses yang terjadi serta kemampuan siswa untuk berperilaku secara efektif dalam kelompok. Studi mengenai interaksi antar individu dalam kelompok pertama kali diperkenalkan oleh Kurt Lewin (Johnson, 1982: 15) yang menekankan bahwa untuk mempelajari dan memahami tentang dinamika kelompok adalah dengan cara menerapkannya (learning by doing). Penerapan dinamika kelompok bisa dilakukan melalui guidance courses dengan menggunakan sejumlah teknik seperti diskusi kelompok, bermain peran, observasi terhadap jalannya proses kelompok, pemberian umpan balik, prosedur menangani dan mengelola kelompok. Teknik-teknik tersebut, dapat mempengaruhi perilaku siswa untuk membiasakan diri bekerja bersama dan bekerjasama dalam situasi kelompok. Membiasakan siswa aktif dalam kegiatan kelompok bisa meningkatkan kepercayaan dirinya, karena kepercayaan diri siswa hanya bisa dirasakan langsung oleh dirinya sendiri dan tampak pada hubungannya dengan siswa lain.

Berdasarkan hasil observasi dan pengamatan peneliti, laporan guru mata pelajaran, dan wali kelas diperoleh data bahwa ada beberapa siswa kelas VIII di SMP Negeri 3 Libureng Kabupaten Bone yang mengalami kepercayaan diri dalam mengemukakan pendapat kurang terutama dalam kegiatan pembelajaran di kelas. Disamping itu, konselor dalam pengamatan sehari-hari di sekolah menemukan siswa yang mengalami masalah kurang percaya diri terutama dalam mengemukakan pendapat. Kepercayaan diri siswa dalam mengemukakan pendapat kurang, tampak pada kegiatan bimbingan kelompok di kelas. Pakta di lapangan menunjukkan bahwa dalam layanan bimbingan dan konseling baik individual maupun kelompok yang dilakukan konselor sebagai tindak lanjut dari laporan guru mata pelajaran dan wali kelas memperkuat penilaian bahwa terdapat beberapa siswa yang memiliki kepercayaan diri kurang. Fenomena kurang kepercayaan diri dalam mengemukakan pendapat dapat dilihat pada sikap seperti rendah diri, pemalu, tidak berani mengemukakan pendapat dalam proses belajar di kelas, tidak berani bertanya atau menjawab pertanyaan baik dari guru maupun dari teman-teman, kurang pandai bercakap-cakap, tidak mampu menarik perhatian dan minat orang lain, tidak berpartisipasi dalam kegiatan belajar kelompok, dan tidak mampu bersaing dengan teman-teman lainnya di sekolah. 
Berkaitan dengan permasalahan kepercayaan diri siswa dalam mengemukakan pendapat di SMP Negeri 3 Libureng yang dapat berimplikasi pada perkembangan kepribadian siswa secara keseluruhan, maka diperlukan upaya untuk mengatasinya. Salah satu teknik bimbingan yang dapat digunakan untuk membantu meningkatkan kepercayaan diri siswa dalam mengemukakan pendapat adalah melalui teknik diskusi kelompok dan role playing. Dikemukakan oleh Glanz (1974) bahwa guidance courses bisa dilakukan melalui teknik diskusi kelompok, role playing dan teknik-teknik lain yang memberi peluang individu melakukan kerjasama. Kegiatan diskusi kelompok dan role playing dapat membantu siswa lebih mengenal lingkungannya secara nyata, melakukan kerjasama yang lebih harmonis, belajar tentang aturan dan peran tertentu, mampu menirukan dan menemukan pikiran-pikiran serta hubungan yang lebih bermakna. Dipertegas Romlah (1989) bahwa role playing membantu anak-anak dapat belajar berbagai macam pengetahuan yang memungkinkan mereka untuk mengembangkan pengenalan terhadap lingkungan. Role playing merupakan cara belajar yang menyenangkan, karena dengan bermain anak-anak belajar sesuatu tanpa menyadarinya. Role playing merupakan suatu teknik bimbingan kelompok yang memberikan kesempatan kepada para siswa untuk memecahkan masalah dengan cara bermain peran. Adapun teknik diskusi kelompok diharapkan bahwa setiap siswa secara aktif mengambil bagian untuk mengemukakan pendapat ataupun pengalaman-pengalamannya sehingga siswa yang lain dalam kelompok dapat mengambil manfaat dari pendapat dan pengalaman yang dikemukakan oleh teman-temannya. Kegiatan dinamika kelompok dalam guidance courses, dapat menciptakan hubungan dan komunikasi yang efektif antar siswa dalam kelompok. Komunikasi efektif tampak pada suasana kelompok yang anggotaanggotanya mampu mengembangkan sikap saling menghargai, dapat mengungkapkan masalahnya dalam kegiatan kelompok, mampu mengemukakan pendapatnya secara jelas, dan dapat memikul tanggung jawab bersama.

Peran kelompok sebagai wadah untuk mengembangkan potensi siswa di sekolah perlu dicermati oleh konselor di sekolah, karena tidak selalu mudah mewujudkan kelompok yang dinamis. Persoalannya adalah guru pembimbing dalam realitanya belum mengetahui bagaimana melaksanakan dinamika kelompok dalam guidance courses melalui teknik diskusi kelompok dan role playing serta bagaimana teknik tersebut dapat meningkatkan kepercayaan diri siswa dalam mengemukakan pendapat secara optimal. Penerapan dinamika kelompok dalam guidance courses menarik untuk diteliti karena belum banyak penelitian yang mengkaji secara mendalam masalah tersebut kaitannya dengan kepercayaan diri siswa dalam mengemukakan pendapat sebagai obyek penelitiannya.

Penelitian yang ditemukan sebelumnya antara lain, dilakukan oleh Lasitosari (2006) yang menyimpulkan bahwa bimbingan kelompok efektif untuk meningkatkan kepercayaan diri bagi siswa yang tidak naik kelas. Tujuan penelitian untuk memperoleh informasi empiris secara deskriptif tingkat kepercayaan diri siswa yang tidak naik kelas sebelum dan sesudah mengikuti kegiatan bimbingan kelompok dan untuk menguji keefektifan layanan bimbingan kelompok dalam meningkatkan kepercayaan diri siswa yang tidak naik kelas di SMA Negeri 7 Semarang. Berdasarkan hasil pre test, kepercayaan diri siswa kelas X dan XI yang tidak naik kelas berada dalam kategori rendah, berarti kepercayaan diri siswa baik dalam kepercayaan diri batin, lahir, maupun spiritual rendah. Setelah mendapatkan bimbingan kelompok, kepercayaan diri siswa yang tidak naik kelas menunjukkan adanya peningkatan, sehingga bimbingan kelompok efektif untuk meningkatkan kepercayaan diri siswa yang tidak naik kelas.

Adapun Kuswanto (2000) meneliti tentang kepercayaan diri antara siswa yang diberi dan tidak diberi bimbingan pribadi melalui layanan bimbingan kelompok disimpulkan bahwa bimbingan pribadi melalui layanan bimbingan kelompok berpengaruh secara signifikan untuk meningkatkan kepercayaan diri siswa. Penelitian yang dilakukan oleh Ibadah, (2008) mengenai upaya meningkatkan kepercayaan diri melalui bimbingan dan konseling islami pada siswa kelas X MA Al-Asror Semarang. Hasil penelitian menunjukkan bahwa tingkat kepercayaan diri siswa pada kondisi awal secara keseluruhan mencapai skor rendah dan setelah perlakuan terjadi peningkatan kepercayaan diri. Artinya media bimbingan yang digunakan dalam pelaksanaan bimbingan dan konseling islami bisa meningkatkan kepercayaan diri. Kemudian Penelitian oleh Ratnasari, (2009) tentang hubungan antara kepercayaan diri dengan keterampilan komunikasi interpersonal siswa SMA Negeri 1 Srengat Blitar menunjukkan bahwa sangat sedikit (19,81\%), siswa SMA Negeri 1 Srengat yang memiliki tingkat kepercayaan diri pada klasifikasi sangat tinggi, banyak $(76,42 \%)$ siswa SMA Negeri 1 Srengat yang memiliki tingkat kepercayaan diri pada klasifikasi tinggi, dan sangat sedikit (3,77\%) siswa SMA Negeri 1 Srengat yang memiliki tingkat kepercayaan diri pada klasifikasi rendah. Adapun untuk keterampilan komunikasi interpersonal menunjukkan bahwa sangat sedikit $(6,60 \%)$ siswa yang memiliki tingkat keterampilan komunikasi interpersonal pada klasifikasi sangat tinggi, banyak $(83,96 \%)$ siswa SMA Negeri 1 Srengat yang memiliki keterampilan komunikasi interpersonal pada klasifikasi tinggi, dan sangat sedikit $(9,43 \%)$ siswa SMA Negeri 1 Srengat yang memiliki tingkat keterampilan komunikasi interpersonal pada klasifikasi rendah. Serta Penelitian yang dilakukan Cucu Sutisna (2010) tentang peningkatan kepercayaan diri siswa melalui strategi layanan bimbingan kelompok, studi eksperimen di SMAN 6 Bandung menunjukkan bahwa layanan bimbingan kelompok efektif untuk meningkatkan kepercayaan diri siswa SMAN 6 Bandung 
Dari temuan penelitian di atas, peneliti melihat ada sisi menarik yang belum dikaji secara mendalam oleh peneliti-peneliti terdahulu yaitu penelitian yang menekankan pada aspek kekuatan, semangat dan dinamika kelompok dalam guidance courses melalui diskusi kelompok dan role playing untuk meningkatkan kepercayaan diri siswa dalam mengemukakan pendapat. Dinamika kelompok dalam guidance courses menarik diteliti untuk memperoleh penjelasan-penjelasan empiris tentang bagaimana pengaruh penerapan dinamika kelompok dalam guidance courses terhadap kepercayaan diri siswa dalam mengemukakan pendapat, ide atau gagasan dalam kegiatan belajar kelompok di kelas.

Alasan memilih sekolah ini, pertama karena memang terdapat siswa SMP Negeri 3 Libureng Kabupaten Bone menunjukkan kepercayaan diri mengemukakan pendapat rendah, yang ditunjukkan oleh sikap siswa yang tidak dapat mengambil bagian dalam kegiatan belajar berkelompok, kedua dalam usaha sosialisasi akan lebih mudah karena telah mengenal personil sekolah, ketiga teknik diskusi kelompok dan role playing belum pernah diteliti di sekolah tersebut, keempat kepercayaan diri siswa dalam mengemukakan pendapat rendah karena metode ceramah dan penugasan sangat mewarnai kegiatan pembelajaran di kelas, artinya guru mata pelajaran lebih senang menggunakan metode pembelajaran secara konvensional yang mengakibatkan siswa tidak memiliki kebiasaan dalam mengemukakan pendapatnya dalam kegiatan belajar kelompok atau di depan orang lain. Disamping alasan tersebut, peneliti juga berasumsi bahwa dengan penerapan dinamika kelompok dengan guidance courses melalui teknik diskusi kelompok dan role playing dapat pula memacu peningkatan kemampuan siswa untuk membangun hubungan baik antar sesama, membangun interaksi, dan bekerjasama satu sama lain, sehingga mendorong terwujudnya kepercayaan diri siswa. Karena dengan membiasakan diri berkomunikasi dengan orang lain dalam berbagai situasi berarti memberikan kesempatan kepada siswa untuk menyatakan pikiran, gagasan, dan ide-ide yang dimilikinya. Kegiatan belajar berkelompok dan bimbingan kelompok perlu diberikan ruang yang luas untuk mengoptimalkan potensi sosial siswa sebagai mahluk individu dan sosial. Berkaitan dengan permasalahan tersebut, peneliti tertarik untuk mengkaji melalui penelitian dengan pendekatan pra-eksperimen dengan judul "Pengaruh penerapan dinamika kelompok dalam guidance courses terhadap kepercayaan diri siswa dalam mengemukakan pendapat".

Tujuan penelitian adalah: (1) Untuk mengetahui gambaran kepercayaan diri siswa dalam mengemukakan pendapat sebelum dan sesudah penerapan dinamika kelompok dalam guidance courses pada SMPN 3 Libureng Kabupaten Bone; (2) Untuk mengetahui pengaruh penerapan dinamika kelompok dalam guidance courses terhadap kepercayaan diri siswa dalam mengemukakan pendapat pada SMP Negeri 3 Libureng Kabupaten Bone.

\section{Metode}

Penelitian ini adalah penelitian eksperimen dengan jenis pre-experimental design. Rancangan penelitian ini memiliki karakteristik utama yaitu (1) subyek penelitian hanya satu kelompok, yakni kelompok eksperimen, (2) pemberian pretest dan posttest untuk subyek penelitian, dan (3) kontrol validitas internal dan eksternal terbatas (Tuckman, B. 1999). Desain penelitian ini menggunakan the one-group pretest-posttest design

Populasi dalam penelitian ini adalah semua siswa kelas VIII SMP Negeri 3 Libureng Kabupaten Bone. Accessible populations meliputi semua siswa kelas VIII SMP Negeri 3 Libureng Kabupaten Bone yang terdaftar pada tahun pelajaran 2010/2011 sebanyak 104 orang. Penetapan Accessible populations yaitu siswasiswa di sekolah tersebut diasumsikan memiliki karakteristik yang sama yaitu berasal dari keluarga dengan latar budaya yang sama, semua siswa adalah kelas VIII, mengalami masa transisi, dan berada pada lingkungan sekolah yang relatif sama.

Sampel yang diambil adalah siswa kelas VIII. Penentuan sampel menggunakan teknik purpossive sampling, yaitu teknik pengambilan sampel dengan pertimbangan bahwa siswa yang terpilih tersebut mengalami kepercayaan diri dalam mengemukakan pendapat kurang berdasarkan indikator yang sudah ditentukan sebelumnya. Indikator kepercayaan diri siswa adalah keyakinan atas kemampuan yang dimiliknya sehingga siswa tidak merasa ragu-ragu, optimis, obyektif, bertanggungjawab, rasional dan realistis. Maka terjaring 30 orang siswa kelas VIII SMP Negeri 3 Libureng Kabupaten Bone yang teridentifikasi mengalami kepercayaan diri dalam mengemukakan pendapat kurang pada saat mengikuti kegiatan belajar kelompok di kelas. Siswa yang terjaring kemudian diberikan pre-test untuk menentukan base line data. Instrumen yang digunakan dalam penelitian ini, yaitu (1) bahan perlakuan, dan (2) instrumen pengumpulan data.

Bahan perlakuan penelitian ini berbentuk panduan dinamika kelompok dalam guidance courses (panduan diskusi kelompok dan role playing). Panduan diskusi kelompok dan role playing dikembangkan dengan pola pengembangan yang mengadaptasi model pengembangan pendidikan dengan menambahkan uji ahli sebelum produk akhir (Mahmud, A. 2005: 68). Prosedur pelaksanaan penelitian mulai dari 
identifikasi masalah, identifikasi tujuan, penyusunan perangkat perlakuan, penyusunan skenario pelaksanaan, uji coba ahli dan produk akhir.

Setelah uji coba ahli akan dilakukan revisi berdasarkan saran-saran yang diberikan dalam angket validasi. Produk hasil revisi inilah yang dinyatakan layak untuk menjadi bahan perlakuan diskusi kelompok dan role playing. Panduan umum, panduan khusus, dan media penunjang yang telah direvisi dan dinyatakan layak, digandakan untuk dijadikan bahan perlakuan diskusi kelompok dan role playing.

Perlakuan yang diberikan kepada subyek penelitian adalah latihan diskusi kelompok dan latihan role playing. Materi dalam latihan diskusi kelompok dan role playing di isi tentang cara membangun kepercayaan diri melalui hubungan kerjasama yang baik, interaksi, dan membina kebersamaan dalam kelompok. kegiatan dari setiap bentuk perlakuan dimulai dari (1) Latihan Diskusi Kelompok yang memiliki 8 pertemuan kemudian; (2) Latihan Role Playing yang Role playing dilaksanakan untuk membantu siswa berlatih memerankan tokoh-tokoh atau situasi tertentu untuk menggali kemampuan pribadi dan sosial dan membantu pula siswa menumbuhkan kepercayaan dirinya. Role playing memiliki 9 pertemuan dan Pertemuan terakhir memberikan Post-test.

Instrumen pengumpulan data yang digunakan dalam penelitian ada dua jenis yaitu pengumpul data yang bersifat primer dan pengumpul data yang bersifat sekunder. Pengumpul data primer adalah skala penilaian kepercayaan diri siswa dalam mengemukakan pendapat. Skala kepercayaan diri dalam mengemukakan pendapat merupakan pengukuran yang tidak dapat dinyatakan dengan respon benar atau salah. Skala penilaian kepercayaan diri dikembangkan menurut penyusunan alat ukur sebagai berikut. Pengembangan alat ukur diawali kegiatan pengembangan spesifikasi skala kepercayaan diri siswa dalam mengemukakan pendapat. Pengembangan spesifikasi skala kepercayaan diri mengikuti langkah-langkah, yaitu (1) membuat rumusan tujuan berdasarkan konstruk kepercayaan diri siswa dalam mengemukakan pendapat, (2) menetapkan deskripsi subyek pengukuran skala penilaian, (3) menetapkan jumlah pernyataan dengan mempertimbangkan reliabilitas, ketersediaan waktu dan perkiraan motivasi subyek, (4) alokasi waktu untuk mengerjakan, dan (5) menyusun kisi-kisi skala penilaian kepercayaan diri mengemukakan pendapat. Setelah spesifikasi dinyatakan layak kemudian dilakukan penulisan pernyataan. Pernyataan skala kepercayaan diri siswa dalam mengemukakan pendapat berbentuk skala likert. Tingkat pengukurannya interval, sedangkan kategori jawaban terdiri atas 5 tingkatan. Respon yang diharapkan oleh subyek adalah taraf kesetujuan atau ketidaksetujuan dalam bentuk variasi angka dengan pilihan (5) sangat setuju, (4) setuju, (3) kurang setuju, (2) tidak setuju, (1) sangat tidak setuju. Isi pernyataan terdiri dari penyataan yang mendukung teori (favourable statement) dan pernyataan yang tidak mendukung teori (unfavourable statement). Pernyataan yang mendukung teori dinilai dengan skor 5 bermakna sangat tinggi, skor 4 bermakna tinggi, skor 3 bermakna sedang, skor 2 bermakna rendah, dan skor 1 bermakna sangat rendah. Sebaliknya, pernyataan yang tidak mendukung teori diberi penilaian dengan skor 5 bermakna sangat rendah, skor 4 bermakna rendah, skor 3 bermakna sedang, skor 2 bermakna tinggi, dan skor 1 bermakna sangat tinggi. Pernyataan yang telah tersusun, kemudian dilakukan penelaahan untuk mengetahui validitas pernyataan skala kepercayaan diri siswa dalam mengemukakan pendapat. Pernyataan ditelaah dari tiga arah, yaitu (1) kesesuaian dengan kisi-kisi, (2) kesesuaian dengan dasar teori, (3) kelayakan dan ketepatan pembahasan. Berdasarkan hasil penelaahan dilakukan perakitan pernyataan. Penyusunan pernyataan di dalam skala kepercayaan diri mengemukakan pendapat dilakukan secara acak untuk menghindari terjadinya respon sesuatu pernyataan dipengaruhi oleh respon terhadap pernyataan yang lain. Pengacakan dilakukan terhadap segi isi pernyataan, maupun dari segi favourable statement dan unfavourable statement. Pernyataan skala kepercayaan diri siswa dalam mengemukakan pendapat berjumlah 65 item pernyataan sebagai hasil rakitan yang diujicobakan terhadap subyek coba yang mirip subyek penelitian. Subyek uji coba berjumlah 50 siswa kelas VIII di SMP Negeri 3 Libureng tetapi bukan siswa yang akan dikenai perlakuan. Uji coba dilakukan untuk pengujian validitas dan reliabilitas skala kepercayaan diri siswa dalam mengemukakan pendapat dengan cara meminta siswa memberikan tanda dari pernyataan-pernyataan skala kepercayaan diri siswa dalam mengemukakan pendapat. Hasil uji validitas angket dengan menggunakan pengolahan komputer program SPSS 17,0 for windows ditemukan bahwa dari 65 item pernyataan, yang tidak valid sebanyak 17 item karena nilai $\mathrm{r}$ hitung yang diperoleh $<$ (lebih kecil atau kurang) dari 0,388 yaitu nomor $2(0,184)$, nomor $15(0,016)$, nomor $18(0,144)$, nomor 19 $(0,347)$, nomor $20(0,021)$, nomor $23(0,358)$, nomor $26(0,246)$, nomor $35(0,137)$, nomor $36(-0,220)$, nomor $37(-0,390)$, nomor $42(0,250)$, nomor $45(-0.096)$, nomor $48(0,348)$, nomor $49(0,083)$, nomor 50 $(0,367)$, nomor $54(-0.159)$ dan nomor $56(-0.048)$, sehingga angket setelah uji validitas sebanyak 48 item pernyataan.

Adapun hasil uji reliabilitas angket penelitian sebesar 0.945. Suatu alat ukur dikatakan memiliki realibilitas yang baik bilamana alat ukur tersebut memberikan skor yang relatif sama pada seorang responden, jika responden tersebut mengisi angket pada waktu yang tidak bersamaan atau pada tempat yang berbeda, walaupun harus memperhatikan adanya aspek persamaan karakteristik. Dari hasil uji keterbacaan dilakukan perakitan pernyataan ke dalam perangkat instrumen skala kepercayaan diri siswa 
dalam mengemukakan pendapat dengan menggunakan pertimbangan-pertimbangan seperti pada saat uji coba.

Langkah terakhir pengembangan instrument adalah penetapan subyek, prasyarat kondisi pengukuran, alokasi waktu untuk mengerjakan keseluruhan tes dan waktu untuk masing-masing bagian dan kondisi lain yang dibutuhkan. Pengembangan alat ukur dilakukan sebelum kegiatan di lapangan dan dikerjakan secara simultan dengan pengembangan bahan perlakuan.

Pengumpul data yang bersifat sekunder digunakan obervasi untuk mencatat kejadian-kejadian, perubahan, reaksi-reaksi dan partisipasi siswa selama mengikuti pelaksanaan diskusi kelompok dan role playing. Adapun aspek-aspek yang diobservasi adalah partisipasi, toleransi, tanggungjawab, perhatian, inisiatif, dan kerjasama dengan cara memberi tanda cek $(\sqrt{ })$ setiap aspek yang muncul pada kegiatan diskusi kelompok dan role playing. Kemunculan setiap aspek pada waktu pengamatan, selanjutnya dilakukan penghitungan untuk menentukan tingkat partisipasi siswa dalam kegiatan diskusi kelompok dan role playing tersebut (Abimanyu, 1983: 26).

\section{Hasil Dan Pembahasan}

Berdasarkan hasil Penelitian dengan menggunakan Pra-eksperimen yang dilakukan terhadap 30 siswa mengenai penerapan dinamika kelompok dalam guidance courses terhadap kepercayaan diri siswa dalam mengemukakan pendapat pada SMP Negeri 3 Libureng Kabupaten Bone sebelum dan sesudah perlakuan berupa pelatihan diskusi kelompok dan role playing. Hasil penelitian ini akan dikaji dengan menggunakan analisis statistik deskriptif untuk menggambarkan tingkat kepercayaan diri siswa dalam mengemukakan pendapat sebelum dan sesudah diberi perlakuan diskusi kelompok dan role playing, dan uji hipotesis penelitian untuk mengetahui adanya pengaruh penerapan dinamika kelompok dalam guidance courses terhadap kepercayaan diri siswa dalam mengemukakan pendapat pada SMP Negeri 3 Libureng Kabupaten Bone.

Analisis statistik deskriptif dimaksudkan untuk memperoleh gambaran mengenai kepercayaan diri siswa dalam mengemukakan pendapat sebelum dan sesudah perlakuan diskusi kelompok dan role playing terhadap siswa kelas VIII pada SMP Negeri 3 Libureng Kabupaten Bone, maka berikut ini akan disajikan dalam bentuk tabel distribusi frekuensi yang diklasifikasikan dalam lima kategori, yaitu (1) tingkat kepercayaan sangat tinggi, (2) tinggi, (3) sedang, (4) rendah, dan (5) sangat rendah dengan hasil sebagai berikut.

Tabel 4.1. Gambaran Kepercayaan Diri Siswa Sebelum dan Sesudah Diberikan Perlakuan Diskusi Kelompok dan Role Playing Di SMP Negeri 3 Libureng Kabupaten Bone

\begin{tabular}{cccccc}
\hline \multirow{2}{*}{ Interval } & \multirow{2}{*}{ Kategori } & \multicolumn{2}{c}{ Pretest } & \multicolumn{2}{c}{ Posttest } \\
\cline { 3 - 6 } & Sangat Tinggi & - & - & - & - \\
\hline $204-241$ & Trekuensi & Persentase & Frekuensi & Persentase \\
$165-203$ & Sedang & - & - & 18 & $60 \%$ \\
$126-164$ & Rendah & 30 & $100 \%$ & 12 & $40 \%$ \\
$87-125$ & Sangat Rendah & - & - & - & - \\
$48-86$ & Jumlah & 30 & 100,00 & 30 & - \\
& & & & - & 100,00 \\
\hline
\end{tabular}

Dari Tabel 4.1. menunjukkan bahwa sebelum diberikan perlakuan diskusi kelompok dan role playing, kepercayaan diri siswa dalam mengemukakan pendapat di SMP Negeri 3 Libureng Kabupaten Bone berada dalam ketegori rendah sebanyak 30 siswa (100\%), dan tidak ada siswa yang berada dalam kategori sangat rendah, sedang, tinggi, dan sangat tinggi. Selanjutnya, sesuai dengan nilai rata-rata skor yang diperoleh siswa sebesar 118,63 atau 119 (pembulatan), dimana nilai rata-rata tersebut, pada interval 87-125 yang berarti rendah. Hal ini berarti bahwa tingkat kepercayaan diri siswa dalam mengemukakan pendapat di SMP Negeri 3 Libureng berada dalam kategori rendah. Secara visual gambaran umum score pre-test kepercayaan diri siswa dalam mengemukakan pendapat terlihat pada grafik berikut. 


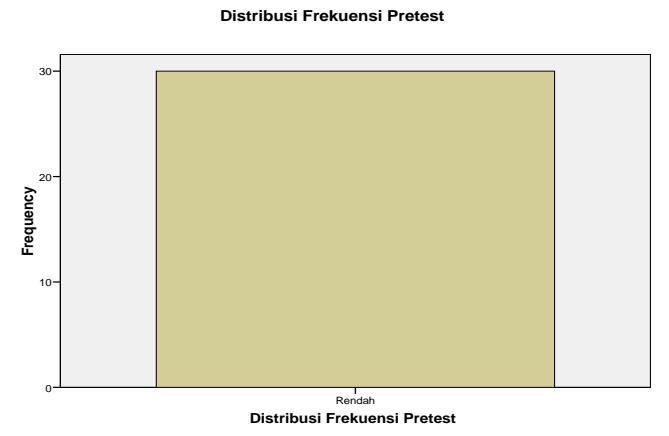

\section{Grafik 4.1. Gambaran Umum Score Pre-Test Kepercayaan Diri Siswa dalam Mengemukakan Pendapat}

Berdasarkan Grafik 4.1 menunjukkan bahwa sebelum diberikan perlakuan diskusi kelompok dan role playing kepercayaan diri siswa dalam mengemukakan pendapat terbukti berada pada kategori rendah. Artinya siswa mengalami kesulitan berpartisipasi, bertoleransi, memikul tanggung jawab, iniastif, membangun kerjasama dalam kegiatan kelompok.

Setelah diberikan perlakuan diskusi kelompok dan role playing masing-masing sebanyak 9 kali pertemuan dan 4 sesi inti termasuk diskusi kelompok terfokus, ternyata kepercayaan diri siswa dalam mengemukakan pendapat di SMP Negeri 3 Libureng kabupaten Bone mengalami peningkatan. Peningkatan dapat dilihat dari tingkat kepercayaan diri siswa dalam mengemukakan pendapat dominan pada kategori tinggi sebanyak 18 siswa (60\%), kategori sedang sebanyak 12 siswa (40\%), tidak ada siswa yang berada dalam kategori rendah, sangat rendah, dan sangat tinggi. Sesuai dengan nilai rata-rata skor yang diperoleh siswa dalam kategori tinggi sebesar 167,23 atau 167 (pembulatan), dimana nilai rata-rata tersebut, berada pada interval 165-203 yang berarti tinggi. Hal ini berarti bahwa terdapat 18 siswa mengalami tingkat kepercayaan diri siswa dalam mengemukakan pendapat dalam kategori tinggi. Adapun nilai rata-rata skor yang diperoleh siswa dalam kategori sedang berada pada interval 138-164 yang berarti sedang. Hal ini berarti bahwa terdapat 12 siswa mengalami tingkat kepercayaan diri dalam mengemukakan pendapat dalam kategori sedang. Perubahan ini menunjukkan bahwa kepercayaan diri siswa dalam mengemukakan pendapat mengalami peningkatan setelah diberikan perlakuan diskusi kelompok dan role playing. Secara visual gambaran umum score post-test kepercayaan diri siswa dalam mengemukakan pendapat terlihat pada grafik berikut.

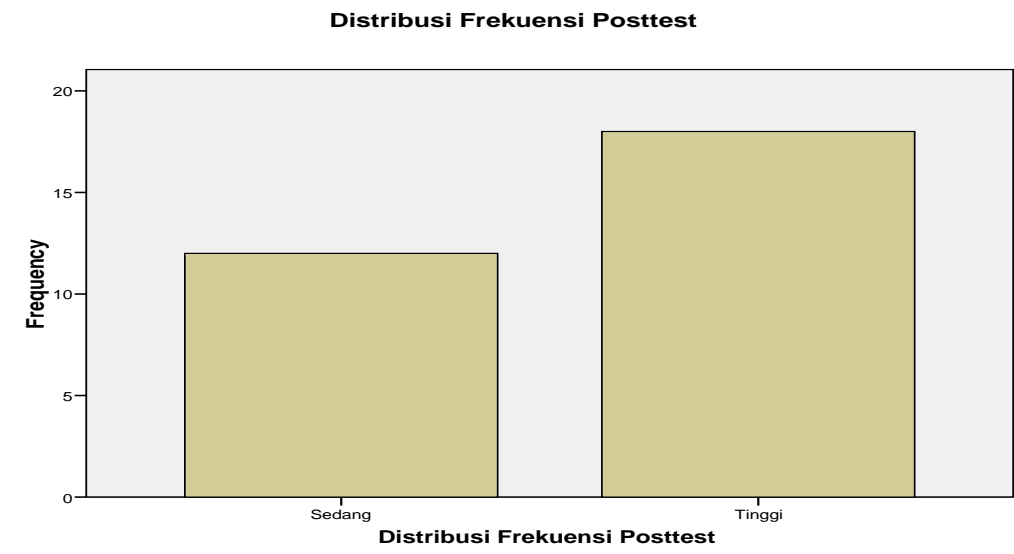

\section{Grafik 4.2 Gambaran Umum Score Post-Test Kepercayaan Diri Siswa dalam Mengemukakan Pendapat.}

Berdasarkan Grafik 4.2 menunjukkan bahwa skor hasil post-test kepercayaan diri siswa dalam mengemukakan pendapat setelah diberikan perlakuan diskusi kelompok dan role playing mengalami peningkatan.

Selain data analisis statistik deskriptif, juga ditemukan data yang terkait dengan kepercayaan diri siswa dalam mengemukakan pendapat melalui kegiatan diskusi kelompok dan role playing. Data hasil observasi yang diperoleh pada setiap aspek dari pelaksanaan diskusi kelompok dan role playing dapat diuraikan sebagai berikut. 
Data hasil observasi pertemuan pertama diskusi kelompok yang dilakukan terhadap 30 siswa pada aspek, yaitu (1) partisipasi terdapat 14 siswa yang tidak mengajukan pertanyaan, menjawab pertanyaan, dan memberi penjelasan. Terdapat 4 siswa yang mengajukan pertanyaan dan memberi penjelasan serta 12 siswa yang dapat mengajukan pertanyaan atau menjawab pertanyaan saja, (2) toleransi meliputi bicara tahu waktu, mau mendengar pendapat orang lain, sabar menunggu giliran berbicara, persedia mendukung pendapat orang lain, juga belum tergambar dengan baik. Siswa berbicara semaunya saja tanpa memperhitungkan waktu dan tidak memanfaatkan waktu berbicara yang baik, (3) tanggung jawab meliputi melaksanakan perintah, melaksanakan tugas, berani menerima tantangan dalam kelompok, dan mengikuti kegiatan kelompok. Berani menerima tantangan dalam kelompok adalah aspek yang sangat kurang meskipun siswa secara sadar dan sukarela mengikuti latihan diskusi kelompok tersebut, (4) perhatian meliputi berpartisipasi aktif selama latihan berlangsung, sukarela mengikuti kegiatan, kesediaan untuk berbicara, dan bahasa tubuh tertuju pada pusat pembicaraan. Kesediaan untuk berbicara dalrm kegiatan kelompok sangat kurang meskipun tanpaknya peserta sangat serius mengikuti semua kegiatan, (5) inisiatif terdapat 16 siswa yang tidak memberi ide-ide baru, mengajukan usul, mengajukan alternatif, dan mengambil prakarsa, serta terdapat 1 siswa yang tidak dapat membangun kerjasama dalam kegiatan kelompok. Kemampuan mengajukan alternatif dan mengambil prakarsa adalah aspek yang paling kurang dilakukan peserta diskusi, dan (6) kerjasama meliputi saling memberi pendapat, saling membantu kesulitan dalam kelompok, bekerjasama mempelajari tugas, dan menyelesaikan tugas kelompok secara bersama-sama. Saling memberi pendapat dalam latihan diskusi kelompok merupakan aspek paling kurang dilakukan peserta diskusi kelompok. Hal ini dapat dipahami karena kemampuan siswa untuk menyesuaikan diri dalam kegiatan kelompok membutuhkan waktu.

Hasil observasi pertemuan kedua yang dilakukan terhadap 30 siswa pada aspek, yaitu (1) partisipasi terdapat 13 siswa yang tidak mengajukan pertanyaan, menjawab pertanyaan, dan memberi penjelasan. Terdapat 3 siswa yang dapat mengajukan pertanyaan, menjawab pertanyaan dan memberikan penjelasan dan 5 siswa yang hanya dapat mengajukan pertanyaan, menjawab pertanyaan atau memberikan penjelasan. Memberikan penjelasan merupakan aspek yang mengalami peningkatan cukup lambat dalam diskusi kelompok, tetapi pertemuan kedua mengalami kemajuan dibanding pertemuan pertama, (2) toleransi menunjukkan pula peningkatan pada dua aspek yakni mau mendengar pendapat orang lain dan bersedia mendukung pendapat orang lain, (3) tanggung jawab meliputi melaksanakan perintah dan mengikuti kegiatan kelompok menunjukkan peningkatan yang signifikan tetapi berani menerima tantangan dalam kelompok dan melaksanakan tugas masih kurang, (4) perhatian meliputi berpartisipasi aktif selama latihan berlangsung, sukarela mengikuti kegiatan, kesediaan untuk berbicara, dan bahasa tubuh tertuju pada pusat pembicaraan. Kesediaan untuk berbicara dalam kegiatan kelompok dan bahasa tubuh tertuju pada pusat pembicaraan meningkat meskipun tampaknya perhatian peserta perlu lebih antusias mengikuti semua kegiatan, (5) inisiatif meliputi, memberi ide-ide baru, mengajukan usul, mengajukan alternatif, mengambil prakarsa. Kategori rendah masih terdapat pada mengajukan usul dan mengajukan alternatif, dan (6) kerjasama meliputi, saling memberi pendapat, saling membantu kesulitan dalam kelompok, bekerjasama mempelajari tugas, dan menyelesaikan tugas kelompok secara bersamasama. Saling memberi pendapat dalam latihan diskusi kelompok menunjukkan peningkatan yang sangat berarti.

Hasil observasi pertemuan ketiga diskusi kelompok yang dilakukan terhadap 30 siswa pada aspek, yaitu (1) partisipasi meliputi mengajukan pertanyaan, menjawab pertanyaan, memberi penjelasan, terdapat 2 siswa yang belum antusias mengikuti kegiatan diskusi kelompok, sedangkan lainnya mengalami peningkatan, (2) toleransi meliputi bicara tahu waktu, mau mendengar pendapat orang lain, sabar menunggu giliran berbicara, bersedia mendukung pendapat orang lain, menglami peningkatan yang sangat signifikan. Hasil observasi terlihat pada keaktifan siswa yang semakin meningkat, (3) tanggung jawab meliputi melaksanakan perintah, melaksanakan tugas, berani menerima tantangan dalam kelompok, dan mengikuti kegiatan kelompok. Aspek tanggung jawab pada pertemuan ketiga menunjukkan peningkatan yang sangat berarti, (4) perhatian meliputi berpartisipasi aktif selama latihan berlangsung, kesediaan untuk berbicara, dan bahasa tubuh tertuju pada pusat pembicaraan masih kurang, tetapi suka rela mengikuti kegiatan berlangsung sangat bagus. Suasana tampak pada peserta yang sangat serius mengikuti semua kegiatan, (5) inisiatif meliputi memberi ide-ide baru, mengajukan usul, mengajukan alternatif, mengambil prakarsa. Terdapat 8 siswa yang kurang partisipasinya dalam mengembangkan inisiatif, sedangkan terdapat 22 siswa yang mengalami perkembangan signifikan. Kemampuan mengajukan alternatif dan mengambil prakarsa adalah aspek yang paling kurang dilakukan peserta diskusi, (6) kerjasama meliputi, saling memberi pendapat, saling membantu kesulitan dalam kelompok, bekerjasama mempelajari tugas, dan menyelesaikan tugas kelompok secara bersama-sama mengalami peningkatan sangat baik. Saling memberi pendapat dalam latihan diskusi kelompok merupakan aspek paling kurang dilakukan peserta diskusi kelompok akibat faktor psikologis yang dialaminya dalam kelompok. Artinya secara keseluruhan semua aspek yang diobservasi mengalami peningkatan yang signifikan. 
Hasil observasi pertemuan keempat diskusi kelompok terfokus yang dilakukan terhadap 30 siswa pada aspek, yaitu (1) aspek partisipasi, (2) aspek toleransi, (3) aspek tanggung jawab, (4) aspek perhatian, (5) aspek inisiatif, dan (6) aspek kerjasama, menunjukkan bahwa semua siswa dapat berpartisipasi secara aktif dalam kegiatan diskusi kelompok terfokus (lihat lampiran 15 panduan observasi diskusi kelompok hal. 250). Dari hasil observasi pelaksanaan diskusi kelompok tersebut dapat disimpulkan bahwa setiap sesi pertemuan terjadi peningkatan partisipasi siswa yang mengindikasikan kepercayaan diri siswa dalam mengemukakan pendapat meningkat.

Sedangkan mencermati hasil observasi setiap aspek pada kegiatan role playing diuraikan sebagai berikut.

Hasil observasi pertemuan pertama kegiatan role playing yang dilakukan terhadap 30 siswa yang dimainkan kelompok A sebanyak 10 orang menunjukkan bahwa semua siswa dapat menjalankan perannya secara baik, meskipun siswa nomor 8, 11, 12, 22, 27 dan 28 terlihat ragu-ragu. Adapun siswa nomor 7, 9, 14 dan 19 mampu melakukan perannya dengan sangat baik. Aspek memberikan ide-ide baru, memberikan penjelasan, bisa menimbulkan humor, dan kemampuan memperagakan sesuatu merupakan aspek paling kurang dilakukan peserta dalam latihan role playing.

Hasil observasi pertemuan kedua teknik role playing yang dilakukan terhadap 30 siswa yang dimainkan kelompok B sebanyak 10 orang menunjukkan bahwa semua siswa dapat menjalankan perannya secara baik, meskipun siswa nomor 2, 3, dan 25 terlihat ragu-ragu. Siswa nomor 1, 6, 16, 20, 23, 26 dan 29 mampu melakukan perannya dengan sangat baik. Aspek memberikan ide-ide baru, memberikan penjelasan, bisa menimbulkan humor merupakan aspek paling kurang dilakukan siswa dalam kegiatan role playing.

Hasil observasi pertemuan ketiga teknik role playing yang dilakukan terhadap 30 siswa yang dimainkan kelompok $\mathrm{C}$ sebanyak 10 orang menunjukkan bahwa semua siswa dapat menjalankan perannya secara baik, hanya siswa nomor 3 masih tampak ragu-ragu. Siswa nomor 5, 8, 10, 13, 15, 15, 17, 21, 24, dan 30 mampu melakukan perannya dengan sangat baik. Memberikan penjelasan merupakan aspek paling kurang dilakukan peserta dalam latihan role playing.

Dari hasil observasi pertemuan pertama, kedua, ketiga, dan diskusi kelompok terfokus ditemukan bahwa siswa mengalami kesulitan dalam memberi penjelasan, cara mengajukan pertanyaan, memberi ide-ide baru dan mengajukan alternatif pada kegiatan role playing (lampiran 16. panduan observasi role playing hal. 259). Meskipun terdapat kesulitan bagi siswa dalam kegiatan role playing, namun kesulitan-kesulitan itu dapat dilalui siswa sehingga dapat disimpulkan bahwa setiap pertemuan role playing dapat meningkatkan kepercayaan diri siswa.

Hasil observasi yang dilakukan terhadap 30 subyek penelitian ditemukan 2 orang siswa yakni, Muh. Syarif dan Aprisal mengaku mengalami kesulitan dalam meningkatkan kepercayaan diri mengemukakan pendapat khususnya dalam kegiatan diskusi kelompok di kelas. Mereka mengalami kesulitan untuk mengajukan pertanyaan dalam kegiatan diskusi kelompok. Selain itu, siswa juga mengalami kesulitan dalam menjawab pertanyaan dari teman-teman dalam kelompok apalagi memberikan saran dan sanggahan yang diperlukan bagi teman-temannya dalam kegiatan diskusi kelompok. Terbukti pada pertemuan pertama dan kedua diskusi kelompok keduanya menempati posisi paling rendah tetapi justru mengalami peningkatan pada pertemuan keempat saat diskusi kelompok terfokus. Sebaliknya, Febi pada pertemuan pertama rendah, meningkat pada pertemuan kedua dan ketiga, namun pada pertemuan diskusi kelompok terfokus Febi justru mengalami penurunan. Penurunan terjadi karena kondisi psikologis ketika diskusi kelompok terfokus berbeda pada kondisi setiap siswa. Pada kegiatan latihan role playing mereka mengalami kesulitan dalam memerankan dan memperagakan tugastugas yang diberikan kepadanya. Pernyataan siswa dalam diskusi kelompok terfokus untuk latihan role playing tampak sangat bersemangat, namun masih ada beberapa siswa yang mengalami hambatan dalam melakukan perannya karena keterbatasan bahasa. Hambatan itu terjadi karena latihan role playing tidak disediakan skenario lengkap dengan harapan agar siswa dapat berekspresi sendiri berdasarkan peran-peran yang mereka mainkan. Namun saat diajukan pertanyaan "apakah anda ingin meningkatkan kepercayaan diri dalam mengemukakan pendapat? Keduanya Muh. Syarif dan Aprisal dengan tegas menjawab ya, tetapi ketika ditanya "dengan cara apa?", keduanya terkesan belum tahu. Gambaran ini terlihat dalam kegiatan diskusi kelompok terfokus untuk role playing.

Hipotesis penelitian ini adalah ada pengaruh yang signifikan penerapan dinamika kelompok dalam guidance courses terhadap kepercayaan diri siswa dalam mengemukakan pendapat pada SMP Negeri 3 Libureng Kabupaten Bone. Untuk menjawab permasalahan tersebut diajukan hipotesis nihil $\left(\mathrm{H}_{0}\right)$ yang berbunyi tidak ada pengaruh penerapan dinamika kelompok dalam guidance courses terhadap kepercayaan diri siswa dalam mengemukakan pendapat. Untuk pengujian hipotesis tersebut, maka terlebih dahulu disajikan data perhitungan statistik kepercayaan diri siswa dalam mengemukakan pendapat, baik pre-test maupun post-test. Hasil perhitungan statistik mean pre-test-post-test digambarkan pada tabel 4.2 sebagai berikut. 
Tabel 4.2. Rekapitulasi Hasil Perhitungan Statistik Mean Pretest-Posttest Kepercayaan Diri Siswa "Paired Samples Statistics"

\begin{tabular}{rrrrrr}
\hline & & & & \multicolumn{2}{c}{ Std. Error } \\
Pair 1 & & Mean & N & Std. Deviation & \multicolumn{1}{c}{ Mean } \\
\hline & Pre-test & 118.6333 & 30 & 6.17829 & 1.12800 \\
& Post-test & 167.2333 & 30 & 13.26828 & 2.42244 \\
\hline
\end{tabular}

Data pada tabel 4.2. terlihat hasil perhitungan statistik mean pretest-posttest untuk kepercayaan diri siswa dalam mengemukakan pendapat sebelum dan sesudah perlakuan berbeda secara signifikan. Mean posttest kepercayaan diri siswa dalam mengemukakan pendapat lebih tinggi dari pada mean pretest kepercayaan diri siswa dalam mengemukakan pendapat. Hasil tersebut menunjukkan bahwa setiap responden mengalami peningkatan gain score kepercayaan diri dalam mengemukakan pendapat (lihat lampiran 13. data skor pretest-posttest kepercayaan diri hal. 244). Sedangkan untuk mengetahui apakah dinamika kelompok dalam guidance courses berpengaruh terhadap kepercayaan diri siswa dalam mengemukakan pendapat sebelum dan sesudah perlakuan, maka disajikan hasil perhitungan statistik untuk pengujian hipotesis dengan menggunakan $t$-test yang dilaporkan pada tabel 4.3 sebagai berikut.

Tabel 4.3. Rekapitulasi Hasil Perhitungan Statistik untuk Pengujian Hipotesis Kepercayaan Diri Siswa dalam Mengemukakan Pendapat Paired Samples Test

\begin{tabular}{|c|c|c|c|c|c|c|c|c|}
\hline & \multicolumn{5}{|c|}{ Paired Differences } & & & \\
\hline & \multirow[t]{2}{*}{ Mean } & \multirow{2}{*}{$\begin{array}{c}\text { Std. } \\
\text { Deviation }\end{array}$} & \multirow{2}{*}{$\begin{array}{l}\text { Std.Error } \\
\text { Mean }\end{array}$} & \multicolumn{2}{|c|}{$\begin{array}{l}95 \% \text { Confidence } \\
\text { Interval of the } \\
\text { Difference }\end{array}$} & \multirow[b]{2}{*}{$\mathbf{T}$} & \multirow[b]{2}{*}{ df } & \multirow{2}{*}{$\begin{array}{l}\text { Sig. } \\
\text { (2.Tailed) }\end{array}$} \\
\hline & & & & Lower & Upper & & & \\
\hline $\begin{array}{l}\text { Pair } 1 \text { Posttest- } \\
\text { Pretest }\end{array}$ & 48.600 & 8.139 & 1.486 & 51.639 & 45.561 & 32.705 & 29 & .000 \\
\hline
\end{tabular}

Berdasarkan tabel 4.3. hasil perhitungan statistik dengan menggunakan SPSS 17,0 for windows diperoleh nilai $\mathrm{t}_{\text {hitung }}=32.705>\mathrm{t}_{\text {tabel }}=2.045$ pada $\mathrm{df}=29$ dengan taraf $\alpha=0.05$ yang berarti $\mathrm{t}$ hitung menunjukkan angka yang lebih besar dari pada $\mathrm{t}$ tabel, maka $\mathrm{H}_{0}$ ditolak dan $\mathrm{H}_{1}$ diterima. Hal ini berarti bahwa penerapan dinamika kelompok dalam guidance courses berpengaruh signifikan terhadap kepercayaan diri siswa dalam mengemukakan pendapat pada SMP Negeri 3 Libureng Kabupaten Bone.

Untuk mendukung secara nyata perbedaan tersebut, dapat dibuktikan dengan mean pre-test 118.63 dan mean post-test 167.23 menunjukkan bahwa mean post-test lebih besar dibandingkan mean pre-test dengan selisih 48.600. Kesimpulan yang dapat diambil adalah ada pengaruh yang signifikan penerapan dinamika kelompok dalam guidance courses terhadap kepercayaan diri siswa dalam megemukakan pendapat pada SMP Negeri 3 Libureng Kabupaten Bone.

Untuk lebih mencermati hasil penelitian, maka hasil perhitungan statistik tersebut dicek silang dengan data yang diperoleh melalui diskusi kelompok terfokus pada kegiatan diskusi kelompok dan role playing. Siswa yang mendapatkan gain score tertinggi yaitu, Annisa Risda, Akmarina, Srimelyanti, Salmawati, dan Melisa kepadanya diajukan pertanyaan "apakah anda ingin terus berlatih untuk meningkatkan kepercayaan diri anda? Ia dengan tegas menjawab, "ya" alasannya karena hanya orang yang memiliki kemampuan untuk menjalin hubungan baik, berinteraksi, dan bekerjasama dengan orang lain disekitarnya akan memperkuat kepercayaan dirinya. Ketika kepadanya diajukan lagi pertanyaan dengan cara apa anda bisa meningkatkan kepercayaan diri anda? Ia menjawab "dengan cara terus berlatih berdiskusi dan bermain peranan bersama dengan teman-teman sehingga selalu terbiasa untuk mengemukakan pendapat, gagasan dan ide-ide dalam situasi kelompok.

Siswa yang mendapatkan gain skor sedang, Regitha Asari, Indra PA, Dwiyanti, Bau, Taskiyatul A, Saima, Rismayanti, Misrukiani dengan pertanyaan yang sama tegas menyatakan "ya" ...... saya ingin meningkatkan kepercayaan diri saya sehingga menjadi orang yang pede. Alasan yang dikemukakan adalah orang yang memiliki kepercayaan diri tampak hubungan sosialnya sangat bagus, tidak minder, berani dan tidak ragu-ragu, dapat mengemukakan pendapatnya walaupun itu belum tentu benar. 
Siswa lain yang mempereoleh gain skor paling rendah, yaitu Sudarmawan, Ardi Putra Triguna, dan Sahril dengan tegas pula menjawab "ya", tetapi ketika ditanya "dengan cara apa anda melakukannya?", ketiganya pun terkesan belum tahu. Gambaran ini terlihat dalam kegiatan diskusi kelompok terfokus untuk role playing.

Dari hasil analisis statistik dan penuturan yang terungkap dalam diskusi kelompok terfokus dapat disimpulkan bahwa dinamika kelompok dalam guidance courses berpengaruh terhadap kepercayaan diri siswa dalam mengemukakan pendapatnya. Namun ada gejala yang menarik untuk disimak, bahwa kepercayaan diri siswa dalam mengemukakan pendapat belum tentu sepenuhnya dibarengi dengan perubahan kesadaran diri yang tinggi melalui dinamika kelompok dalam guidance courses semata, tetapi faktor psikologis dari setiap siswa dapat pula mempengaruhi kepercayaan diri siswa itu sendiri. Ketika diajukan pertanyaan apakah anda yakin bahwa dinamika kelompok dalam guidance courses berpengaruh terhadap kepercayaan diri anda dalam mengemukakan pendapat? Jawaban yang diberikan oleh siswa bervariasi, tetapi umumnya memiliki kesamaan bahwa komitmen untuk berubah dapat diperoleh melalui kegiatan kelompok.

Tujuan umum penelitian ini adalah untuk mengetahui gambaran kepercayaan diri siswa dalam mengemukakan pendapat dalam kegiatan belajar dan bimbingan kelompok di kelas. Tujuan khususnya adalah untuk mengetahui apakah ada pengaruh penerapan dinamika kelompok dalam guidance courses melalui diskusi kelompok dan role playing terhadap kepercayaan diri siswa dalam mengemukakan pendapat?

Secara teoritik kepercayaan diri siswa dapat meningkat melalui kegiatan kelompok dan sosial sebagai wadah untuk mengembangkan diri dan menyalurkan potensi yang dimilikinya selaku mahluk individu dan sosial. Adler (Supratiknya, 1993: 241) menyatakan bahwa manusia pada dasarnya adalah makhluk sosial yang selalu menghubungkan dirinya dengan orang lain, ikut dalam kegiatan-kegiatan kerjasama sosial, menempatkan kesejahteraan sosial di atas kepentingan diri sendiri dan mengembangkan gaya hidup yang mengutamakan orientasi sosial. Dapat dikatakan bahwa setiap orang selalu membutuhkan orang lain dan hendaknya dapat bekerjasama dengan orang lain, saling membantu dan memiliki hubungan yang baik dengan banyak orang, sehingga dapat meningkakan kepercayaan dirinya. Persoalannya, apakah kesimpulan teoritis tersebut didukung dengan fakta lapangan? Membuktikan hal tersebut dilakukan pengujian hipotesis penelitian sebagaimana dikemukakan pada bagian pendahuluan tesis ini. Hasil pengujian hipotesis itulah yang menjadi temuan penelitian dan dibahas dalam bagian ini.

\section{Gambaran Kepercayaan Diri Siswa dalam Mengemukakan Pendapat Sebelum dan Sesudah Perlakuan.}

Hasil analisis statistik deskriptif menunjukkan bahwa tingkat kepercayaan diri siswa sebelum diberikan latihan diskusi kelompok dan role playing berada dalam kategori rendah. Rendahnya kepercayaan diri siswa dalam mengemukakan pendapat di SMP Negeri 3 Libureng dapat dilihat pada sikap rendah diri, tidak berani mengemukakan pendapat, gagasan dan ide-ide dalam kegiatan pembelajaran dan bimbingan kelompok di kelas, tidak berani bertanya atau menjawab pertanyaan dari teman-teman maupun gurunya, serta kurang mampu menarik perhatian dan minat teman. Kondisi tersebut terjadi disebabkan karena guru di sekolah pada umumnya menggunakan metode pembelajaran konvensional dan kurang variatif. Guru mata pelajaran dalam proses pembelajaran di sekolah cenderung memandang permasalahan siswa dalam bingkai kolektif sehingga aspek individualitas masing-masing siswa kurang tersentuh secara maksimal. Meskipun sebagian guru mata pelajaran sudah melaksanakan proses pembelajaran secara berkelompok, tetapi kelompok yang terbentuk tidak mendorong siswa untuk lebih memahami potensi dirinya secara optimal.

Sesudah diberikan perlakuan berupa latihan diskusi kelompok dan role playing menunjukkan bahwa kepercayaan diri siswa dalam mengemukakan pendapat meningkat. Indikasi kepercayaan diri siswa meningkat tampak pada tingkat pencapaian partisipasi siswa yang berada pada kategori sedang dan tinggi yang sebelumnya berada pada kategori rendah. Perbedaan tingkat kepercayaan diri siswa dalam mengemukakan pendapat menjadi cermin bahwa penerapan teknik diskusi kelompok dan role playing berperan merubah sikap dan perilaku siswa. Perubahan terjadi berdasarkan perbedaan kemampuan yang dimiliki setiap siswa sebagai individu yang unik. Siswa yang memiliki semangat dan motivasi tinggi untuk berubah senantiasa mendorong dirinya untuk berpartisipasi dalam kegiatan kelompok secara optimal. Namun kemampuan siswa untuk membangun dan meningkatkan kepercayaan diri juga berbeda-beda, tergantung dari kemampuan dasar yang dimilikinya. Hal ini terbukti pada hasil penelitian yang menunjukkan bahwa sesudah perlakuan tingkat kepercayaan diri siswa berada dalam kategori sedang dan tinggi. Temuan tersebut, sejalan pendapat Lauster (1997) yang menyatakan bahwa kepercayaan diri seseorang memang berbeda-beda, ada yang memiliki tingkatan kepercayaan diri rendah, sedang, dan tinggi. Seseorang yang memiliki tingkat kepercayaan diri rendah cenderung merasa tidak bebas, tidak 
enak, cemas, dan tidak nyaman. Bagi orang yang memiliki tingkat kepercayaan diri sedang akan cenderung ragu-ragu, khawatir tentang kesan yang timbul pada diri orang lain dan memiliki rasa rendah diri. Seseorang yang mempunyai kepercayaan diri tinggi ditunjukkan dengan bekerja efektif, mampu melaksanakan tugas-tugas dengan baik, bertanggung jawab dan merencanakan masa depannya sendiri. Siswa yang mengalami kepercayaan diri rendah dan sedang tercermin pula perilaku mereka dalam kegiatan diskusi kelompok dan role playing. Meskipun latihan diskusi kelompok dan role playing sudah dilaksanakan secara berulang, namun keaktifan siswa cenderung masih kurang, kecuali beberapa siswa mulai aktif memberikan pendapatnya dalam kegiatan kelompok. Dibanding sebelum perlakuan, maka keterlibatan siswa untuk mengambil peran dalam mengemukakan pendapat pada kegiatan diskusi kelompok dan role playing mengalami peningkatan. Peningkatan dapat dilihat pada perolehan selisih hasil skor pretest-posttest kepercayaan diri siswa dalam mengemukakan pendapat. Nilai skor posttest kepercayaan diri siswa terbukti lebih tinggi dari pada nilai skor pretest.

Hasil analisis observasi kegiatan diskusi kelompok pada pertemuan pertama terlihat beberapa siswa, yakni Sudarmawan, Aan, Muh. Syarif, Reski, Febi, Aprisal, Aldi A, Sahril, dan Egi berada pada kategori sangat rendah dan meningkat pada pertemuan kedua, kecuali Muh. Syarif dan Aprisal tetap berada pada kategori sangat rendah. Sebaliknya, pada pertemuan kedua terlihat pula dua siswa yang berada pada kategori tinggi, yakni Salmawati dan Akmarina. Keduanya aktif mengajukan pertanyaan maupun memberikan jawaban atas pertanyaan dari teman-temannya pada kegiatan diskusi kelompok, bahkan keduanya mulai aktif memberikan masukan dan usul terhadap pertanyaan pokok diskusi kelompok. Pada pertemuan ketiga dan kegiatan diskusi kelompok terfokus untuk diskusi kelompok menunjukkan partisipasi yang semakin meningkat karena tidak ada lagi siswa yang berada pada kategori sangat rendah. Bahkan ada enam orang siswa berada pada kategori tinggi yakni Salmawati, Regitha, Srimelyanti, Akmarina, Saima, dan Annisa Risda. Siswa yang berada pada kategori tinggi tersebut menunjukkan peningkatan partisipasi dalam hal mengajukan pertanyaan, menjawab pertanyaan, dan memberi tanggapan. Selanjutnya, kemajuan yang dicapai siswa pada setiap pertemuan diskusi kelompok dapat diketahui melalui kegiatan refleksi setiap akhir sesi pertemuan diskusi kelompok. Jawaban yang dikemukakan siswa umumnya merasa puas dan senang dengan teknik diskusi kelompok yang dikelola dengan baik, langkah-langkah kegiatannya tersusun secara jelas dan sistematis. Setiap pertemuan diawali dengan kegiatan ice breaking uintuk mengatasi kebekuan yang dapat terjadi dalam diskusi kelompok.

Adapun partisipasi siswa pada kegiatan role playing tampak pada kategori rendah dan sedang, tidak terdapat siswa yang berada pada kategori sangat rendah, tinggi dan sangat tinggi. Hasil analisis observasi kegiatan role playing dari sesi ke sesi pertemuan menarik untuk dicermati karena merupakan lanjutan kegiatan diskusi kelompok. Hasil observasi membuktikan bahwa terjadi peningkatan yang berarti pada setiap pertemuan dimana partisipasi siswa yang berada pada kategori rendah berkurang dan meningkat pada kategori sedang. Peningkatan tersebut dapat diartikan bahwa kegiatan role playing dapat direkomendasikan untuk membantu siswa berpartisipasi secara aktif dengan cara memerankan tokoh dan situasi tertentu melalui kegiatan kelompok.

Kepercayaan diri siswa melalui kegiatan role playing dapat pula dipengaruhi oleh faktor lain, berupa isi naskah skenario role playing. Naskah yang dimainkan disusun dalam bentuk naskah belum utuh dengan maksud agar siswa dapat melengkapi skenario berdasarkan pemahaman tentang tokoh dan situasi yang diperankannya sendiri. Tujuan akhir yang ingin dicapai adalah agar siswa dapat berekspresi dengan mengembangkan kemampuan mengelola pikiran dan pendapat melalui kalimat yang mereka susun sehingga skenario role playing menjadi lejas dan sempurna. Faktanya, kepercayaan diri siswa tampak meningkat melalui kegiatan dinamika kelompok dengan memanfaatkan teknik diskusi kelompok dan role playing. Peningkatan partisipasi siswa pada kegiatan kelompok tersebut menjadi bukti empiris pendapat yang dikemukakan oleh Shertzer dan Stone (1980: 199) bahwa pengembangan diri siswa adalah pencapaian kemampuan pribadi dan sosial melalui hubungan antar siswa dalam kegiatan kelompok. Hubungan itu berlangsung dengan mengindikasikan adanya prosedur yang berperan untuk mendorong kelompok, artinya dinamika kelompok dengan teknik diskusi kelompok dan role playing dapat digunakan untuk membahas topik-topik yang mendorong pengembangan diri siswa. Temuan penelitian ini, diperkuat pendapat Glanz (1974: 203) yang merekomendasikan teknik guidance courses melalui diskusi kelompok, role playing dan teknik-teknik lain yang memberi peluang siswa melakukan kerjasama antar satu dengan lainnya dalam wujud pengembangan dirinya.

Jadi pada prinsipnya membangun kepercayaan diri siswa sebagai bagian dari proses pengembangan diri berkaitan erat pula dengan unsur psikologis yang dimilikinya dan hanya bisa dirasakan langsung oleh diri siswa yang bersangkutan, tetapi kepercayaan diri bisa pula tampak dalam hubungannya dengan orang lain. Kesuksesan menjalin hubungan dan komunikasi dengan orang lain dalam kelompok banyak bergantung pada tingkat kohesivitas suatu kelompok. Suatu kelompok dikatakan kohesif, jika setiap anggota kelompok tercipta keakraban, tumbuh kesadaran tentang tujuan kelompok dan kegiatan kelompok, serta ikut berpartisipasi aktif pada setiap proses dan sesi kegiatan kelompok. Oleh karena itu, dinamika kelompok harus menjiwai kegiatan kelompok sehingga setiap anggota kelompok dapat memiliki 
semangat dan kekuatan untuk melakukan peran dan fungsi dengan baik. Peningkatan partisipasi siswa dalam kegiatan diskusi kelompok dan role playing menjadi bukti bahwa penelitian ini relevan dengan pendapat yang dikemukakan oleh Shertzer dan Stone (1980: 199) bahwa dinamika kelompok hanya dapat berlangsung dalam kelompok yang benar-benar hidup dan dinamis. Kelompok yang dinamis ditandai adanya kesadaran anggota kelompok untuk membangun hubungan antara sesama, berinteraksi, dan bekerjasama satu sama lain. Dengan demikian dapat disimpulkan bahwa melaksanakan teknik diskusi kelompok dan role playing berdasarkan langkah-langkah yang telah disusun efektif untuk meningkatkan kepercayaan diri siswa dalam mengemukakan pendapat pada kegiatan belajar kelompok dan bimbingan kelompok di kelas.

\section{Peningkatan Kepercayaan Diri Siswa dalam Mengemukakan Pendapat Sesudah Perlakuan}

Hasil pengujian hipotesis menunjukkan bahwa secara umum sesudah perlakuan dinamika kelompok dalam guidance courses melalui teknik diskusi kelompok dan role playing terdapat peningkatan secara signifikan terhadap kepercayaan diri siswa dalam mengemukakan pendapat. Perbedaan terjadi antara mean pretest dan mean posttest kepercayaan diri siswa dalam mengemukakan pendapat, karena sesudah posttest kepercayaan diri siswa meningkat. Hal ini berarti bahwa sesudah diberikan perlakuan diskusi kelompok dan role playing, maka kesadaran dan komitmen siswa untuk membangun dan meningkatkan kepercayaan dirinya mulai muncul. Kesadaran itu tampak pada diri siswa untuk mengambil peran dalam kegiatan diskusi kelompok dan role playing.

Hasil penelitian yang telah dilaksanakan menunjukkan bahwa pada kegiatan pertama dan kedua latihan diskusi kelompok terdapat beberapa siswa yang kurang aktif, tampak ragu dan kurang percaya diri. Namun, pada pertemuan ketiga dan keempat pada latihan diskusi kelompok ternyata semua siswa berusaha untuk menunjukkan partisipasi dengan cara mengajukan pertanyaan atau menjawab pertanyaan dari teman-temannya. Pada kegiatan diskusi kelompok, kepercayaan diri siswa meningkat secara bertahap, yakni kepercayaan diri siswa rendah, sedang, dan tinggi. Hasil penelitian tersebut, relevan dengan temuan Kohn dan Connell (2002: 192) yang menyatakan bahwa pengembangan kepercayaan diri bisa dibangun secara bertingkat dan berurutan sehingga kepercayaan diri tumbuh semakin kuat, fleksibel dan berkarakter. Pada tahap awal, kepercayaan diri berada pada tingkat yang berbasis-kalkulus, dimana individu bersikap dalam situasi tertentu yang layak dipercaya dan tidak dapat dipercaya, dan tahap selanjutnya kepercayaan diri berada pada tingkat yang berbasis identitas, berarti bahwa kepercayaan dibangun untuk saling mengetahui keinginan dan maksud satu sama lain.

Begitu pula pada kegiatan role playing dan diskusi kelompok terfokus untuk role playing menunjukkan hasil yang signifikan peningkatan kepercayaan diri dimana siswa dapat memainkan peran berdasarkan pilihan masing-masing dengan melengkapi naskah skenario role playing sesuai dengan kemampuan siswa. Perubahan sikap yang terjadi pada diri siswa sesudah perlakuan role playing dapat dilihat pada tingkat partisipasi siswa dalam memainkan peran-peran yang diberikan kepadanya. Semua siswa dapat mengikuti kegiatan role playing dengan penuh semangat yang membuktikan bahwa siswa merasa senang dan tertarik cara memperagakannya. Sikap positif yang tampak pada diri siswa sesudah perlakuan role playing mempengaruhi pula pandangan dan keyakinan siswa tentang kepercayaan diri yang dimilikinya. Hasil penelitian ini, sejalan dengan temuan hasil penelitian yang dilakukan oleh Kadek Suhardita tahun 2011 tentang efektivitas penggunaan teknik permainan dalam bimbingan kelompok untuk meningkatkan percaya diri siswa (Penelitian quasi eksperimen pada Sekolah Menengah Atas Laboratorium (Percontohan) UPI Bandung). Hasil penelitian menunjukkan bahwa terdapat perubahan yang signifikan percaya diri siswa setelah diberikan intervensi penggunaan teknik permainan dalam bimbingan kelompok, sehingga disimpulkan bahwa penggunaan teknik permainan dalam bimbingan kelompok efektif digunakan untuk meningkatkan kepercayaan diri siswa.

Kepercayaan diri yang meningkat setelah perlakuan memperkuat pula pandangan Lauster (Ghufron \& Risnawita, 2010: 36) yang menyatakan bahwa seseorang dikatakan memiliki kepercayaan diri apabila dalam dirinya mulai tumbuh keyakinan akan kemampuan yang dimilikinya, selalu bersikap positif memandang dirinya dan kemampuannya, mampu memahami permasalahan secara obyektif, bertanggung jawab terhadap tindakannya, dapat menganalisa masalah yang dialaminya dengan menggunakan pikiran yang dapat diterima oleh akal mereka sendiri.

Partisipasi siswa dalam latihan diskusi kelompok dan role playing yang sebelumnya kurang lalu meningkat menjadi sedang dan tinggi menunjukkan bahwa perubahan terjadi karena siswa secara bertahap dapat menjalin hubungan baik, berinteraksi satu sama lain, dan bekerjasama dalam kegiatan kelompok. Kemampuan siswa mengambil peran dalam kelompok akan merubah perasaan rendah diri, ragu-ragu dalam kelompok menjadi lebih yakin karena terjalin rasa kebersamaan dalam suasana kelompok. Dalam memaknai kegiatan role playing, maka setiap akhir sesi pertemuan dilakukan refleksi untuk menangkap 
perasaan dan persepsi siswa. Hasil refleksi menunjukkan bahwa setiap siswa yang sudah melakukan role playing merasa senang dan berharap agar kegiatan tersebut dapat pula diterapkan dalam proses belajar.

Hasil analisis statistik menunjukkan pula bahwa sesudah perlakuan diskusi kelompok dan role playing kepercayaan diri siswa dalam mengemukakan pendapat meningkat secara signifikan. Namun, dalam diskusi kelompok yang dilaksanakan terdapat dua orang siswa yang mengalami kesulitan untuk mengajukan pertanyaan dan menjawab pertanyaan dalam kegiatan diskusi kelompok, tetapi justru mengalami peningkatan pada pertemuan keempat saat diskusi kelompok terfokus. Sebaliknya, Febi pada setiap pertemuan diskusi kelompok menunjukkan peningkatan, namun pada pertemuan diskusi kelompok terfokus Febi justru mengalami penurunan. Penurunan terjadi karena kondisi psikologis ketika diskusi kelompok terfokus berbeda pada kondisi setiap siswa. Kondisi psikologis yang dimaksud adalah bahwa ketika diskusi kelompok terfokus dilaksanakan, tampaknya siswa berhasil mengubah kesadaran dan keyakinan pada diri siswa untuk bangkit dari pengalaman beberapa sesi pertemuan pada kegiatan diskusi kelompok maupun role playing. Kenyataan ini terlihat pada keberanian dan kesadaran siswa untuk berpartisipasi aktif dalam kegiatan kelompok dengan alasan bahwa hanya orang yang memiliki kemampuan untuk menjalin hubungan baik dan berinteraksi dengan orang lain disekitarnya yang pada gilirannya dapat memperkuat kepercayaan dirinya. Alasan ini pula yang mendorong siswa untuk terus berlatih berdiskusi dengan teman-teman dan bermain peranan sehingga terbiasa untuk mengemukakan pendapat, gagasan, dan ide-idenya dalam kegiatan kelompok.

Hasil posttest menunjukkan bahwa kepercayaan diri siswa dalam mengemukakan pendapat mengalami peningkatan. Peningkatan terjadi karena siswa menyadari bahwa potensi yang dimilikinya perlu dikembangkan diantaranya melalui kegiatan diskusi kelompok dan role playing Dari temuan-temuan tersebut, dapat disimpulkan bahwa terjadinya perubahan dan peningkatan kepercayaan diri siswa dalam mengemukakan pendapat sesudah diberikan perlakuan diskusi kelompok dan role playing, bisa menjadi bukti empirik atas pernyataan yang dikemuakan oleh Lindenfield (1997: 15) menyatakan bahwa untuk mengembangkan percaya diri, seseorang perlu menjalin hubungan baik dengan siapapun, baik orangorang yang sudah dikenal maupun mampu menjalin hubungan baik dengan orang-orang baru, karena dengan berhubungan orang lain akan menumbuhkan rasa percaya diri. Menjalin hubungan baik dengan orang lain dapat dilakukan dalam kegiatan diskusi kelompok dan role playing.

Demikian pula dengan pernyataan Hakim (2005: 136-147) bahwa cara membangun kepercayaan diri melalui dunia pendidikan antara lain, "memupuk keberanian untuk mengemukakan pendapat, gagasan dan ide-ide. Hal ini sejalan dengan yang dikemukakan oleh Huraerah \& Purwanto (2006: 46) bahwa anggota kelompok yang mempunyai tingkat kepercayaan diri tinggi akan lebih terbuka di dalam mengemukakan pendapat, opini, gagasan dan ide-ide yang dimilikinya. Sebaliknya siswa yang mempunyai tingkat kepercayaan diri rendah akan selalu menghindar, takut, tidak jujur, ragu-ragu dan tidak hati-hati dalam berkomunikasi.

Penerapan dinamika kelompok dalam guidance courses melalui teknik diskusi kelompok dan role playing, dapat digunakan untuk memberikan informasi-informasi yang bisa membantu pengembangan diri siswa. Selain itu, bisa juga digunakan untuk meningkatkan kerjasama interaksi antar satu dengan yang lain. Di dalam kelompok kemudian siswa dibantu mengoreksi sumber-sumber yang mempengaruhinya sehingga tidak bisa berinteraksi satu sama lain (Glanz, 1974: 203).

Dengan demikian diskusi kelompok dan role playing dapat digunakan untuk mendorong pengembangan diri siswa dalam membangun hubungan antar sesama, berinteraksi satu sama lain, dan bekerjasama antar siswa dalam kegiatan kelompok. Kemampuan membangun human relation dapat memperkokoh semangat untuk meningkatkan kepercayaan diri terutama dalam mengemukakan pendapat, gagasan, dan ide-ide dalam kelompok.

\section{Implikasi Hasil Penelitian}

Ada tiga aspek utama yang perlu mendapat perhatian untuk mengembangkan profesi bimbingan konseling yakni teori, penelitian dan praktik bimbingan konseling itu sendiri. Khusus praktik bimbingan konseling yang berlangsung di sekolah selama ini masih menggunakan paradigma yang bertolak dari teoriteori bimbingan konseling konvensional dengan sejumlah asumsi bahwa manusia umumnya diposisikan sama sehingga perlakuan terhadap mereka juga sama. Kondisi seperti ini terus berkembang di sekolahsekolah meskipun terdapat beberapa perubahan sebagai akibat peningkatan kesadaran akan perbedaan individual dalam memberikan layanan. Praktik bimbingan dan pembelajaran di sekolah berlangsung apa adanya tanpa memberikan jaminan layanan paripurna bagi setiap siswa yang memiliki karakteristik yang berbeda-beda. Proses bimbingan dan pembelajaran di kelas dikemas secara sederhana, sehingga menjadi salah satu tantangan pengembangan profesi bimbingan konseling ke depan. Penerapan belajar dan bimbingan konseling kelompok juga masih berjalan secara tradisional dengan teknik yang kurang variatif. Model bimbingan kelompok dengan teknik diskusi kelompok harus dikemas menarik agar siswa yang mengikuti layanan merasa tertarik dan tertantang untuk meningkatkan kepercayaan diri dalam 
hubungannya dengan orang lain. Mereka mampu mengemukakan pendapatnya, gagasan dan ide-ide cemerlang dalam kegiatan kelompok.

Implikasi terhadap penelitian bimbingan konseling, bahwa pengaruh penerapan dinamika kelompok dalam guidance courses terhadap kepercayaan diri siswa dalam mengemukkan pendapat meningkat, tetapi belum semua siswa yang diberikan perlakuan dinamika kelompok melalui teknik diskusi kelompok dan role playing secara otomatis meningkat kepercayaan dirinya dalam mengemukakan pendapat. Terdapat beberapa siswa yang menunjukkan antusiasme masih kurang dalam mengambil peran aktif dalam kegiatan diskusi kelompok dan role playing. Temuan-temuan penelitian tersebut bisa menjadi bukti bahwa konselor dan peneliti selanjutnya perlu menggalakan penelitian untuk mengembangkan model dinamika kelompok yang lebih beragam dan populasi yang yang lebih luas. Bahan-bahan perlakuan dinamika kelompok dalam guidance courses dalam penelitian tersebut bisa menjadi titik tolak, minimal dijadikan sebagai bahan pertimbangan untuk penelitian lanjutan.

\section{Simpulan Dan Saran}

Berdasarkan hasil penelitian tentang pengaruh penerapan dinamika kelompok dalam guidance courses untuk meningkatkan kepercayaan diri siswa dalam mengemukakan pendapat pada SMP Negeri 3 Libureng Kabupaten Bone, dapat dikemukakan beberapa kesimpulan (1) Gambaran kepercayaan diri siswa dalam mengemukakan pendapat sebelum diberikan perlakuan dinamika kelompok dalam guidance courses melalui teknik diskusi kelompok dan role playing berada pada kategori rendah, sedangkan sesudah diberikan perlakuan dinamika kelompok dalam guidance courses melalui teknik diskusi kelompok dan role playing, maka kepercayaan diri siswa dalam mengemukakan pendapat berada pada kategori sedang dan tinggi. (2) Ada pengaruh positif penerapan dinamika kelompok dalam guidance courses terhadap kepercayaan diri siswa dalam mengemukakan pendapat pada SMP Negeri 3 Libureng Kabupaten Bone. Sesudah diberikan perlakuan teknik diskusi kelompok dan role playing kepercayaan diri siswa meningkat yang dibuktikan dengan mean posttest lebih besar dibanding mean pretest. Artinya siswa dapat berpartisipasi dalam kegiatan diskusi kelompok dan dapat memainkan peran dalam suasana kelompok.

Berdasarkan temuan penelitian, pembahasan dan kesimpulan hasil penelitian ini, maka diajukan saran-saran sebagai berikut: (1) Guru bimbingan dan konseling diharapkan memanfaatkan dinamika kelompok dalam guidance courses melalui teknik diskusi kelompok dan role playing dalam sebagai salah satu alternatif untuk membantu mengembangkan sikap dan pola hidup yang lebih baik, optimis, rasional dan bertanggung jawab. Dinamika kelompok dalam guidance courses terbukti berpengaruh secara signifikan terhadap kepercayaan diri siswa. Dinamika kelompok melalui teknik diskusi kelompok dan role playing hendaknya dilaksanakan dengan frekuensi waktu yang memadai, dikembangjan dengan berbagai startegi yang menarik dan kreatif sehinggga para siswa dapat berpartisipasi aktif dalamkegiatan belajar kelompok dan bimbingan kelompok; (2) Pihak sekolah diharapkan menjadikan dinamika kelompok dalam guidance courses melalui teknik diskusi kelompok dan role playing sebagai model yang dapat diterapkan pada kegiatan belajar kelompok dan bimbingan kelompok sebagai salah satu wadah bagi pengembangan diri siswa dalam hubungannya antara satu dengan lainnya. Guru dan siswa diharapkan selalu memanfaatkan teknik diskusi kelompok dan role playing dalam situasi kelompok, sehingga siswa memiliki kebiasaan mengemukakan pendapat, gagasan dan ide-ide dalam hubungannya dengan orang lain; (3) Bagi peneliti selanjutnya dapat meneliti aspek-aspek dinamika kelompok dalam guidance courses melalui teknik-teknik tertentu untuk pengembangan diri siswa yang pada gilirannya dapat meningkatkan kepercayaan diri sebagaimana telah diuraikan pada bagian pembahasan. Aspek partisipasi dan pengembangan inisiatif dalam penelitian ini menunjukkkan peningkatan yang sangat kecil. Pada penelitian ini penulis tidak memberikan refleksi secara keseluruhan setiap akhir kegiatan diskusi kelompok dan role playing untuk setiap kelompok, tetapi refleksi hanya dilakukan pada akhir diskusi kelompok dan role playing untuk semua kelompok, sehingga ada pengalaman penting yang dialami oleh siswa bisa luput dari penilaian penulis. Untuk itu pada penelitian selanjutnya sebaiknya peneliti melakukan refleksi setiap akhir kegiatan diskusi untuk mengetahui dan memahami perkembangan siswa setelah mengikuti kegiatan dinamika kelompok melalui diskusi kelompok dan role playing, sehingga data dapat lebih dilengkapi disamping data skala kepercayaan diri dan data hasil observasi. Subyek dalam penelitian ini adalah siswa-siswa yang memiliki tingkat kepercayaan diri rendah. Peneliti selanjutnya dapat mencoba melakukan penelitian dengan menyertakan satu atau lebih siswa yang memiliki kepercayaan diri tinggi dan sangat tinggi untuk membantu siswa lainnya sebagai partner pembimbing dalam rangka membantu meningkatkan kepercayaan diri teman-temannya, dan diupayakan supaya siswa tersebut tidak diketahui sebagai siswa yang membantu pembimbing. Peneliti selanjutnya yang berminat mengembangkan kepercayaan diri siswa agar hasil penelitian ini dikaji lebih lanjut. Metodologi yang digunakan sebaiknya memakai true-eksperimental dengan adanya kelompok kontrol, sehingga tingkat kepercayaan diri siswa dan pengaruh dinamika kelompok 
dalam guidance courses melalui diskusi kelompok dan role playing bisa dibandingkan antara kelompok kontrol dengan kelompok eksperimen.

\section{Daftar Rujukan}

Abimanyu, S. 1983. Teknik Pemahaman Individu (Teknik Non Tes). Ujung Pandang: IKIP Ujung Pandang

Ghufron, N dan Risnawita, R. 2010. Teori-Teori Psikologi. Yogyakarta: Ar-Ruzz Media.

Glanz, E. C. 1974. Guidance: Foundation, Principles and Techniques. Secon Edition. Boston: Allyn and Bacon. Inc.

Hakim. T. 2005. Mengatasi Rasa Tidak Percaya Diri. Jakarta: Puspa Swara.

Huraerah, A. dan Purwanto. 2006. Dinamika Kelompok-Konsep dan Aplikasinya. Bandung: Refika Aditama.

Ibadah M. 2008. Upaya Meningkatkan Kepercayaan Diri Melalui Bimbingan dan Konseling Islami. Skripsi (Tidak Diterbitkan). Jurusan Bimbingan Konseling. Semarang: FIP Unes.

Kohn, S. E. dan O'Connell, V. D. 2009. 6 Habits of Highly Effective Teams. (Alih Bahasa: Debbie Deci Natalia, A. Md.). Tangerang: Binarupa Aksara Publisher.

Kuswanto. 2000. Kepercayaan Diri Antara Siswa yang Diberi dan Tidak Diberi Bimbingan Pribadi Melalui Layanan Bimbingan Kelompok. Skripsi (Tidak Diterbitkan) Semarang: FIP Unes.

Lasitosari, D. 2006. Keefektifan Bimbingan Kelompok untuk Meningkatkan Kepercayaan Diri Siswa yang Tidak Naik Kelas. Skripsi (Tidak Diterbitkan). Semarang: FIP Unes.

Lauster, P. 1992. Tes Kepribadian. Penerjemah. D. H. Gulo. Jakarta: ANS Sungguh Bersaudara.

Lindenfield, G. 1998. Mendidik Anak Agar Percaya Diri (Alih Bahasa: Ediati Kamil). Jakarta: Arcon.

Mahmud, A. 2005. Penerapan Konseling Kelompok Berwawasan Jender untuk Meningkatkan Rasa Keberhasilan dalam Karier (Career Self-Efficacy) Siswa: Studi Pra-eksperimental di SMA Negeri 9 Makassar. Desertasi (Tidak Diterbitkan). Universitas Negeri Malang.

Pusat Bahasa Depdiknas. 2007. Kamus Besar Bahasa Indonesia Ed.3. Jakarta: Balai Pustaka.

Ratnasari, D. 2009. Hubungan antara Kepercayaan Diri dengan Keterampilan Komunikasi Interpersonal Siswa SMA Negeri 1 Srengat Blitar. Skripsi, (Tidak Diterbitkan). Jurusan Bimbingan Konseling dan Psikologi Fakultas Ilmu Pendidikan Universitas Negeri Malang.

Romlah, T. 2006. Teori dan Praktek Bimbingan Kelompok. Malang: Penerbit Universitas Negeri Malang.

Shertzer \& Stone. 1980. Fundamentals of Guidance. Fourth Edition. Boston: Houghton Mifflin Company.

Suhardita, K. 2011. Efektivitas Penggunaan Teknik Permainan dalam Bimbingan Kelompok untuk Meningkatkan Percaya Diri Siswa (Penelitian Quasi Eksperimen Pada Sekolah Menengah Atas Laboratorium Percontohan UPI Bandung). Tesis (Tidak Diterbitkan). Program Studi Bimbingan dan Konseling. Sekolah Pascasarjana Universitas Pendidikan Indonesia.

Supratiknya. 1993. Teori-Teori Psikodinamik (Klinis). Yogyakarta: Kanisius.

Sutisna, C. 2010. Peningkatan Kepercayaan Diri Siswa Melalui Startegi Layanan Bimbingan Kelompok (Studi Eksperimen di SMAN 16 Bandung Tahun 2009/2010). Tesis (Tidak Diterbitkan). Program Studi Bimbingan dan Konseling. Sekolah Pascasarjana Universitas Pendidikan Indonesia.

Tuckman. B. 1999. Conducting Educational Research. Fifth Edition. Orlando: Harcourt Brace College Publishers.

Winkel, W. S dan Hastuti, S. 2004. Bimbingan dan Konseling di Institusi Pendidikan. Yogyakarta. Media Abadi. 